\title{
Forage production from fine branches and sprouts of native maniçoba
}

\section{Produção de forragem de ramos e rebrotas de maniçoba nativa}

\author{
João Alberto Ferreira Rangel ${ }^{1 *}$; Olaf Andreas Bakke²; José Evanaldo Rangel da \\ Silva ${ }^{3}$; Izabela Souza Lopes Rangel ${ }^{4}$
}

\begin{abstract}
The growth and forage production of Manihot glaziovii were evaluated in plants growing in ItapetimPE, Brazil via a complete block experimental design with four treatments $(0,33,50$, and $100 \%$ branch cutting intensity) to analyze increases in height and diameter. Furthermore, $3 \times 2$ factorial treatments (three branch cutting intensities: 33,50 , and $100 \%$ as well as two types of collected forage material: Branches with diameter $<10 \mathrm{~mm}$ and corresponding sprouts on the same branches 1 year after being cut) were analyzed for improvement in forage quantity and quality parameters. Height increase was affected $(\mathrm{P}<0.05)$ by branch cutting intensity $\left(0.29,0.11,0.43\right.$, and $-0.04 \mathrm{~m} \mathrm{plant}^{-1}$, respectively, for $0,33,50$, and $100 \%$ branch cutting intensities), while the increase in diameter was not affected (P > $0.05)$ (3.97 mm plant ${ }^{-1}$ was the overall mean increase). Cutting intensity $\times$ type of collected material, in combination, affected $(\mathrm{P}<0.05)$ the quantity of the collected forage: means were considered similar $(\mathrm{P}>0.05)$ in the first (branches) and second (sprouts) forage collection events for $33 \%(0.66$ and 0.75 $\mathrm{kg}$ dry matter plant ${ }^{-1}$, respectively) and $50 \%$ (1.40 and $1.73 \mathrm{~kg}^{\text {dry matter plant }}{ }^{-1}$, respectively) cutting intensities; it decreased $(\mathrm{P}<0.05)$ from the first to the second collection events, when $100 \%$ of branches and sprouts were harvested (3.37 and $2.06 \mathrm{~kg}_{\text {dry matter plant }}{ }^{-1}$, respectively). The combined effects of aforementioned parameters were observed $(\mathrm{P}<0.05)$ as interactions for some forage quality variables. Neutral detergent fiber content remained constant $(\mathrm{P}>0.05)$ between 50.57 and $54.41 \%$ in forage containing branch and sprouts from 33 and $50 \%$ cutting intensities. It increased $(\mathrm{P}<0.05)$ to $62.20 \%$ in sprouts from $100 \%$ cutting intensity. Acid detergent fiber content increased $(\mathrm{P}<0.05)$ from around $38.4 \%$ to $46.63 \%$ in sprouts from plants subjected to $100 \%$ cutting intensity. The crude protein (between 8.72 and $10.08 \%$ ) and ether extract (between 2.74 and $4.35 \%)$ contents were unaffected $(\mathrm{P}>0.05)$ by these factors. Mineral matter content was higher $(\mathrm{P}<0.05)$ in sprouts from all cutting intensities with $5.9 \%$ being the highest. Up to $50 \%$ of Manihot glaziovii branches with $\varnothing<10 \mathrm{~mm}$ and corresponding 1 -year-old sprouts can be pruned with no negative effect on the quality and quantity (up to $1.73 \mathrm{~kg}$ dry matter plant $\left.{ }^{-1}\right)$ of the collected forage.
\end{abstract}

Key words: Forage tree. Cutting intensity. Manihot glaziovii. Semiarid.

1 Eng $^{\mathrm{o}} \mathrm{Agr}^{\circ}$, M.e em Zootecnia, Técnico em Agropecuária, Departamento de Ciência Animal, Universidade Federal da Paraíba, UFPB, Centro de Ciências Humanas, Sociais e Agrárias, CCHSA, Bananeiras, PB, Brasil. E-mail: jafrangel@yahoo.com.br

2 Eng $^{\mathrm{o}}$ Agr $^{\mathrm{o}}$, Zootecnista, Prof. Dr., Unidade Acadêmica de Engenharia Florestal, Universidade Federal de Campina Grande, UFCG, Centro de Saúde e Tecnologia Rural, CSTR, Patos, PB, Brasil. E-mail: obakke@cstr.ufcg.edu.br

3 Eng ${ }^{\circ}$ Florestal, M.e em Ciências Florestais pelo Programa de Pós-Graduação em Ciências Florestais, UFCG, Centro de Saúde e Tecnologia Rural, CSTR, Patos, PB, Brasil. E-mail: naldoflorestal@yahoo.com.br

4 Eng $^{\mathrm{o}}$ Florestal, Prof ${ }^{\mathrm{a}} \mathrm{Dr}^{\mathrm{a}}$, Departamento de Agricultura, UFPB, Centro de Ciências Humanas, Sociais e Agrárias, CCHSA, Bananeiras, PB, Brasil. E-mail: izabelaisl@yahoo.com.br

* Author for correspondence 


\section{Resumo}

O crescimento e a produção de forragem de Manihot glaziovii foram avaliados em plantas se desenvolvendo em Itapetim-PE, Brasil, através de um experimento no delineamento em blocos casualizados com 4 tratamentos (intensidades de corte dos ramos: 0, 33, 50 e 100\%) para analisar o aumento em altura e diâmetro. Adicionalmente, foram considerados $3 \times 2$ tratamentos fatoriais (três intensidades de corte dos ramos: 33,50 e $100 \%$, e dois tipos de material forrageiro coletado: Ramos com diâmetro $<10 \mathrm{~mm}$ e respectivas rebrotas desses 1 ano após serem cortados) para analisar parâmetros de quantidade e qualidade da forragem. $\mathrm{O}$ aumento na altura foi afetado $(\mathrm{P}<0,05)$ pela intensidade de corte dos ramos $\left(0,29,0,11,0,43\right.$ e $-0,04 \mathrm{~m} \mathrm{planta}^{-1}$, respectivamente para $0 ; 33 ; 50$ e $100 \%$ de intensidade de corte), enquanto o do diâmetro $\left(3,97 \mathrm{~mm}\right.$ planta $\left.^{-1}\right)$ não foi afetado. Houve interação $(\mathrm{P}<0,05)$ entre os fatores estudados para a produção de forragem: as médias foram consideradas semelhantes $(\mathrm{P}>$ $0,05)$ na primeira (ramos) e segunda (rebrotas) coletas para as intensidades de corte $33 \%(0,66$ e $0,75 \mathrm{~kg}$ de matéria seca planta ${ }^{-1}$, respectivamente) e $50 \%$ (1,40 e 1,73kg de MS planta ${ }^{-1}$, respectivamente), e diminuiu da primeira para a segunda coleta $(\mathrm{P}<0,05)$ na intensidade de $100 \%(3,37$ e $2,06 \mathrm{~kg}$ de MS planta $^{-1}$, respectivamente). Foi observada interação entre os fatores para algumas variáveis de qualidade da forragem: os teores de fibra em detergente neutro se mantiveram constantes $(\mathrm{P}>0,05)$, entre 50,57 e $54,41 \%$, na forragem dos ramos e das rebrotas nas intensidades de corte 33 e $50 \%$, e aumentaram (P< 0,05 ) para $62,20 \%$ nas rebrotas das plantas submetidas a $100 \%$ de intensidade de corte; os teores de fibra em detergente ácido aumentaram $(\mathrm{P}<0,05)$ de um patamar em torno de $38,4 \%$ para até $46,63 \%$, nas rebrotas das plantas submetidas a $100 \%$ de intensidade de corte. Os teores de proteína bruta (entre 8,72 e 10,08\%) e extrato etéreo (entre 2,74 e 4,35\%) não foram afetados $(\mathrm{P}>0,05)$. O teor de matéria mineral foi maior $(\mathrm{P}<0,05)$ nas rebrotas nas três intensidades de corte, e chegou a 5,9\%. Pode-se coletar até $50 \%$ dos ramos com $\varnothing<10 \mathrm{~mm}$ de Manihot glaziovii e respectivas rebrotas de um ano sem prejudicar a qualidade e a quantidade (até $1,73 \mathrm{~kg}$ de MS planta ${ }^{-1}$ ) da forragem coletada.

Palavras-chave: Árvore forrageira. Intensidade de corte. Manihot glaziovii. Semiárido.

\section{Introduction}

Manihot glaziovii Muell. Arg. is a tree belonging to the Euphorbiaceae family, which is native to and is widely present in the Caatinga Biome. It presents nutrient-rich tubers, which allow it to resume growth after the first rains of the short annual rainy season (FERREIRA et al., 2009; MOREIRA FILHO et al., 2008; SOUZA et al., 2006). Its senesced leaves are consumed by animals; however, when they are green and photosynthetically active, they contain cyanogenic glycosides in levels that are toxic to ruminants (COSTA et al., 2008; FRANÇA et al., 2010; MEDINA et al., 2009). The quantity of these cyanogenic glycosides is reduced to non-toxic levels ( $43 \%$ or less of the original content) by cutting of fresh fine stems and leaves. The material thus obtained can be consumed by ruminants as silage and hay, representing a strategic source of food in semiarid environments, such as the Caatinga Biome (FRANÇA et al., 2010; GOUVEIA et al., 2015;
RAMOS et al., 2015; SILVA et al., 2015).

Moreira Filho et al. (2008) reported forage production of $1.8 \mathrm{t} \mathrm{DM} \mathrm{ha-1} \mathrm{from} \mathrm{M.} \mathrm{glaziovii}$ planted in a $1.0 \mathrm{~m} \times 1.5 \mathrm{~m}$ grid. This biomass production is similar to that reported by Prestes et al. (2016) for a natural pastureland in traditional cattle ranching regions of the rainy southern subtropical Brazil. Biomass production up to $1.9 \mathrm{t} \mathrm{DM} \mathrm{ha}^{-1}$ was observed, when no soil amendment and fertilization were performed.

Neutral (NDF) and acid (ADF) detergent fiber, crude protein $(\mathrm{CP})$, ether extract $(\mathrm{EE})$, and mineral matter (MM) contents ( $\%$ of DM) in stem and leaf hay of M. glaziovii range between $51.1 \%$ to $53.7 \%$, $39.6 \%$ to $44.5 \%, 10.6 \%$ to $16.8 \%, 2.0 \%$ to $3.7 \%$, and $6.9 \%$ to $10.6 \%$, respectively (ARAÚJO et al., 2009; SOUZA et al., 2006).

Extensive cattle ranching activity, as practiced in the dry tropical region of northeast Brazil, is based 
on native vegetation. It is reported that as the growth of this vegetation reduces severely during the 7- to 8- month-long dry season, fodder scarcity occurs during most of the year (GONZAGA NETO et al., 2001). The same authors also reported that tree fodder is an important part of the diet of animals, especially during the dry season, when senesced leaves are easily available on the forest floor and represent up to $90 \%$ of the ingested food of domestic ruminants. In this regard, Vieira et al. (2005) showed that forage quality of the senesced leaves on the forest floor is lower than the green leaves before senescence. Bakke et al. (2010) highlighted in their study that many native Caatinga trees produce forage, and their fine branches and leaves can be collected at the full vegetative stage, in the rainy season, to feed animals during the dry season, when plant growth is practically non-existent.

This study evaluated the effect of four cutting intensities of branches with $\varnothing<10 \mathrm{~mm}$ on the growth of native Manihot glaziovii trees. Here, we also estimated the forage quantity and quality of the fine branches and corresponding sprouts observed on them a year later.

\section{Material and Methods}

Data collection was carried out in Sítio Goiana, which is located in the municipality of Itapetim in the Pajeú region of Pernambuco, northeast Brazil. Annual rains totaled $750 \mathrm{~mm}$ and $812 \mathrm{~mm}$ in 2010 and 2011, respectively, mostly in the first six months of each year (Table 1).

Table 1. Total and monthly precipitation ( $\mathrm{mm}$ ) observed in two years, Itapetim-PE, Brazil.

\begin{tabular}{|c|c|c|c|c|c|c|c|c|c|c|c|c|c|}
\hline \multirow{2}{*}{ Year } & \multirow{2}{*}{ Total } & \multicolumn{12}{|c|}{ Month } \\
\hline & & Jan & Feb & Mar & April & May & Jun & Jul & Aug & Sept & Oct & Nov & Dec \\
\hline 2010 & 750 & 183 & 94 & 61 & 123 & 2 & 129 & 0 & 0 & 0 & 0 & 0 & 158 \\
\hline 2011 & 810 & 141 & 88 & 124 & 115 & 223 & 25 & 56 & 8 & 2 & 0 & 28 & 0 \\
\hline
\end{tabular}

Source: Instituto Agronômico de Pernambuco - IPA www.ipa.br, accessed in 05/07/2012.

Existing Manihot glaziovii trees in the area regenerate naturally and were thus subjected to a recurrent cutting practice until 2004. The resulting biomass was then removed before cattle and small ruminants were allowed to consume the native herbaceous forage. Furthermore, after the cutting period in 2004, stump sprouts were no more cut because the area was used for agricultural purposes and no animals were allowed in it, at least until 2011, at the end of data collection.

Forty M. glaziovii trees were selected within the area; the smaller ones (mean height and basal diameter were $3.04 \mathrm{~m}$ and $31.71 \mathrm{~mm}$, respectively) were georeferenced and tagged with numbers from 1 to 20, and the taller ones (mean height and basal diameter were $3.56 \mathrm{~m}$ and $45.52 \mathrm{~mm}$, respectively) were similarly georeferenced and tagged with numbers from 21 to 40 . These parameters, especially basal diameter, were used to devise the experimental blocks.

The analyzed variables were tree height and basal diameter that were measured from March 2010 to March 2011 and forage quantity (fresh and dry matter) and quality [dry matter content (DM), neutral (NDF) and acid (ADF) detergent fiber, hemicellulose (HC), crude protein (CP), ether extract (EE), mineral matter (MM), total (TC) and non-fibrous (NFC) carbohydrates] of branches with $\emptyset<10 \mathrm{~mm}$ cut in March 2010. The latter group of parameters was also recorded for branches that developed on trees since the cutting in 2004 and for corresponding sprouts that grew from these cut branches a year later. 
Total tree height and mean basal diameter (30 $\mathrm{cm}$ above ground level) were measured before the first (branches cut in March 2010) and the second (sprouts in March 2011) forage collection. Height was measured by means of a 5-m graduated rod and basal diameters by means of a digital caliper. Height and basal diameter increase was determined by calculating the difference between the 2011 and 2010 values measured in each plant.

After counting of total branches, those with $\varnothing<10 \mathrm{~mm}$ were collected in March 2010, keeping in perspective the branch cutting intensity designated for each plant. The fresh biomass was then weighed using a digital balance. Data on DM production in each plant was obtained by multiplying the value of fresh biomass collected from each plant to the respective percentage of DM in fresh material collected from each treatment in each block (see sampling description in the next paragraph). Data on fresh and dry matter production from sprouts were collected similarly a year later.

The material that was collected from five plants in block 1 and subjected to $33 \%$ fine branch cutting intensity was now mechanically cut into smaller pieces, followed by being mixed together and sampled ( $\sim 350 \mathrm{~g}$ of fresh material) for forage quality analyses. The same procedure was carried out for the five plants subjected to 50 and $100 \%$ branch cutting intensity treatments, resulting in three samples from each block. These sampling procedures were also used to determine fresh and dry biomass from sprouts. These samples were identified, kept in a cooler with ice cubes, and carried to the Laboratory of Food Analyses at the Patos Campus of the Federal University of Campina Grande. These 12 samples (six for each year) were transferred to identified paper bags, weighed using a $0.1 \mathrm{~g}$ precision digital balance, dried in a forced ventilation oven $\left(65^{\circ} \mathrm{C}\right.$ for 72 hours), and weighed again to estimate DM content. The dried material from each sample was ground to pass a $1 \mathrm{~mm}$ sieve; approximately $50 \mathrm{~g}$ from each was then stored in a hermetically closed plastic container following sieving. The chemical composition of the ground material was determined at the Animal Nutrition Laboratory of the Areía Campus of the Federal University of Paraíba according to the protocols described by Silva and Queiroz (2002) for DM, CP, EE, and MM. Neutral and acid detergent fiber contents were determined according to these protocols but with modifications to adapt with the Ankon apparatus. Hemicellulose, TC, and NFC contents were estimated according to the equations: $\mathrm{HC}=\mathrm{NDF}-\mathrm{ADF}$ (SILVA; QUEIROZ, 2002), TC $=100-(\mathrm{CP}+\mathrm{EE}+\mathrm{MM})$, and $\mathrm{NFC}=100-(\mathrm{NDF}+\mathrm{CP}+\mathrm{EE}+\mathrm{MM}) \quad(\mathrm{VAN} \quad \mathrm{SOEST}$; ROBERTTSON; LEWIS, 1991).

Data were analyzed according to a complete block design. Blocks 1 and 2 were composed with the 20 smaller and 20 taller M. glaziovii trees, respectively, as described earlier. Treatments and the number of treatment replications were different according to the variable being analyzed. The increases in height and basal diameter increments were analyzed by considering 4 treatments (4 branch cutting intensities: $0,33,50$, and $100 \%$ of the branches with $\varnothing<10 \mathrm{~mm}$ ) and 5 treatment replications of one plant in each block. The number of degrees of freedom for treatments, blocks, treatment $\times$ block interaction, error, and total were 3, 1, 3, 32, and 39 , respectively, according to recommendations by Vieira and Hoffmann (1989).

Analyses of fresh and dry biomass production considered $3 \times 2$ factorial treatments $(3$ branch cutting intensities: 33,50 , and $100 \%$, and 2 types of collected forage material: branches with $\varnothing<10 \mathrm{~mm}$ and the corresponding sprouts of these cut branches one year later). Furthermore, two replications of one plant of the $3 \times 2$ factorial treatments in each block were also considered. The number of degrees of freedom for factor 1 , factor 2 , factor $1 \times$ factor 2 interaction, factorial treatments, blocks, residue, and total were $2,1,2,5,1,12$, and 23 , respectively. Only 24 (12 in each block) out of the 30 pruned plants were randomly chosen because there were not enough plants available to add one replication of the $3 \times 2$ factorial treatments in each block. 
Independence between data on forage production from branches and sprouts was guaranteed by the following protocol: Twelve plants that were randomly assigned to furnish data on branch forage production were pruned in March 2010 according to branch cutting intensity; while these plants furnished data regarding the branch-based forage, their sprouts were not collected, furnishing no information on sprout forage production in March 2011. Similarly, 12 plants were randomly assigned to furnish data on sprout forage production and had their branches cut in March 2010, but only this data regarding sprout forage production was collected in March 2011 and was considered in the analysis of variance (ANOVA). Moving on, data collected from 30 pruned plants was used to estimate the best polynomial regression model, up to the second degree, that correlated fresh or dry forage production from branches or sprouts $[\mathrm{Y}=\log$ (production) $]$ with cutting intensity $(\mathrm{X})$.

In the analysis of the bromatological variables (DM, NDF, ADF, HC, CP, EE, MM, TC, and NFC as percentage of $\mathrm{DM}$ ), the previously described $3 \times 2$ factorial treatments were considered and replicated (one plot of five plants) once in each block. The number of degrees of freedom for factor 1 , factor 2 , factor $1 \times$ factor 2 interaction, factorial treatments, blocks, error, and total were 2, 1, 2, 5, 1, 4, and 10, respectively (there was a missing plot on the sprout forage data set).

Log transformation was used, whenever necessary, to correct data heteroscedasticity. Variable means for the two types of collected forage material were compared by the ANOVA F-test. Adopted significance level was $\mathrm{P}<0.05$.

\section{Results and Discussion}

Initial mean \pm standard error for tree height and basal diameter measured in March 2010 were $3.04 \pm 0.05 \mathrm{~m}$ and $31.71 \pm 1.78 \mathrm{~mm}$, respectively, considering the 20 plants in block 1 (shorter plants) and $3.56 \pm 0.05 \mathrm{~m}$ and $45.52 \pm 3.21 \mathrm{~mm}$, respectively, considering the 20 plants in block 2 (taller plants).

Height increment observed for the time period between March 2010 and March 2011 was similar $(\mathrm{P}>0.05)$ for the plants from blocks 1 and 2 . It was affected $(\mathrm{P}<0.05)$ by branch cutting intensity, with mean values of $0.29 \mathrm{~m}, 0.11 \mathrm{~m}, 0.43 \mathrm{~m}$, and -0.04 $\mathrm{m}_{\text {plant }}{ }^{-1}$, respectively, for $0,33 \%, 50 \%$, and $100 \%$ cutting intensities. A negative value for increase in height for the branch cutting intensity of $100 \%$ means that the observed one-year sprout growth was not enough to restore tree height to pre-branch cutting values. However, further analyses on other variables should be carried out to help decide on an optimal branch cutting intensity.

Basal diameter increment was not affected $(\mathrm{P}>0.05)$ by the branch cutting intensity and showed an overall mean of $3.97 \mathrm{~mm}$ between March 2010 and March 2011. However, diameter increment was affected $(\mathrm{P}<0.05)$ by the blocks: Increments observed for block 1 plants (shorter plants) averaged at $6.38 \pm 1.47 \mathrm{~mm}$ (mean \pm standard error), while mean value for block 2 plants (taller plants) was $1.56 \pm 0.87 \mathrm{~mm}$. This data suggests that, in the limits of height and diameter considered in this study, shorter trees are less affected by branch removal than the taller trees.

Bakke (2005) observed that average basal diameter increments in Mimosa tenuiflora Willd. Poiret that had no annual branch cutting was 10.43 and $5.61 \mathrm{~mm}$ plant $^{-1}$ from the first to the second year and from the second to the third year, respectively, while plants subjected to $100 \%$ branch cutting annually showed average diameter increments of 4.43 and $0.14 \mathrm{~mm} \mathrm{plant}^{-1}$, respectively; some of these plants died after the second cut. Manihot glaziovii appears to absorb the impacts of branch cutting, probably due to its nutrient-rich tubers, while reserves in $M$. tenuiflora roots are not so beneficial. Additional studies should be carried out to determine how many cuts and of what intensity could be made before diameter increments cease and/or death of the M. glaziovii plants occurs. 
Branch cut intensity $\times$ type of collected forage material interaction affected $(\mathrm{P}<0.05)$ forage production. It was similar $(\mathrm{P}>0.05)$ for the first and second cut with branch cutting intensities $33 \%$ and $50 \%$, and decreased $(\mathrm{P}<0.05)$ for branch cutting intensity of $100 \%$. When $33 \%, 50 \%$, and $100 \%$ of the branches were cut, mean values of fresh forage production were $2.23,4.61$, and $11.17 \mathrm{~kg}$ plant $^{-1}$, respectively. When the sprouts were cut, the respective values were $2.47,5.57$, and 6.75 $\mathrm{kg}$ plant $^{-1}$. On the basis of dry biomass, the mean values of branch forage production were 0.66 ,
1.40 , and $3.37 \mathrm{~kg}$, respectively, for the three cutting intensities; values for corresponding sprouts were $0.75,1.73$, and $2.06 \mathrm{~kg} \mathrm{plant}^{-1}$. This interaction is visualized in Figure 1 as the distance between the lines, which increases progressively. This means that cutting all branches of $M$. glaziovii had a negative effect on sprout-based forage production in the following year, and that this forage type may decrease even more in subsequent years if the same cutting intensity and intervals are maintained, as reported by Bakke (2005) for M. tenuiflora.

Figure 1. Regression models to estimate dry matter (DM) forage production (Y) from native Manihot glaziovii trees according to cutting intensity $(\mathrm{X})$ of their fine branches $(\varnothing<10 \mathrm{~mm})$ or corresponding 1-year-old sprouts.

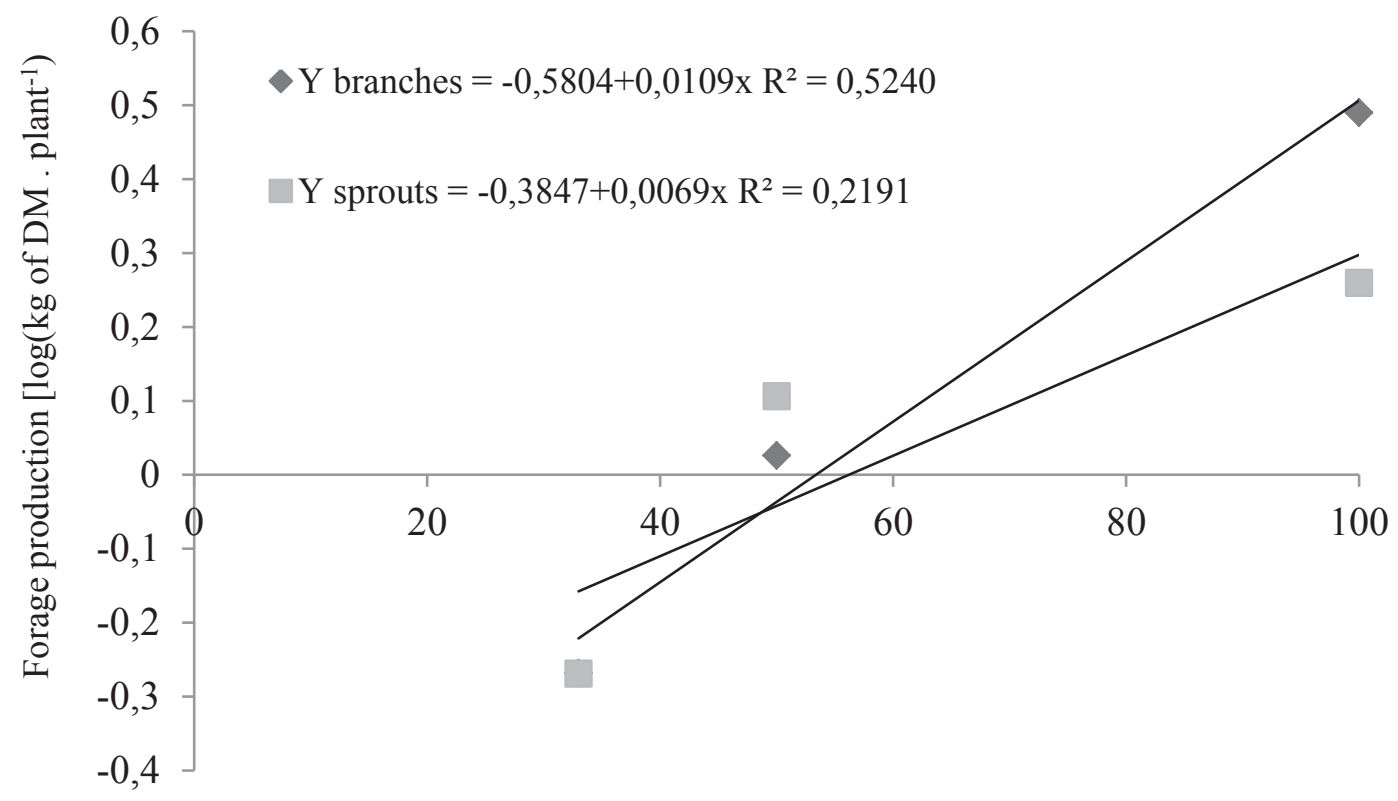

Cut intensity (\%)

Considering that the M. glaziovii trees in the present study were spontaneously grown and received no treatment, such as fertilization or soil amendment, mean biomass production was substantial and higher than those reported for properly cultivated 1 -year-old $(0.26 \mathrm{~kg}$ of fresh biomass plant ${ }^{-1}$ or $0.09 \mathrm{~kg}$ of dry biomass plant $^{-1}$ and 1111 plants ha ${ }^{-1}$ ) (FERREIRA et al., 2009) and for 3-year-old $(0.27 \mathrm{~kg}$ of dry biomass from sprouts plant $^{-1}$ and 6666 plants ha $^{-1}$ ) (MOREIRA FILHO et al., 2008) M. glaziovii plants.

These differences in biomass production certainly result from differences in plant age as well as nutrient accumulation in tubers. In the present study, plants certainly developed for more than six years after they were fully cut in 2004 . In contrast, 
the values reported by other authors corresponded to 1-year-old plants that had lesser time to accumulate their aboveground biomass (FERREIRA et al., 2009) and to 3-year-old plants that had a short time-period to store nutrients in their tubers and favor sprouting (MOREIRA FILHO et al., 2008). This should be considered to be an advantage for old native plants; with thousands of these plants distributed in the Caatinga Biome, they should be used as a feasible source of forage.

Mean forage production reported here is similar to that observed for other trees in dry tropical regions. For example, Drumond et al. (2007) reported $0.69 \pm 0.41 \mathrm{~kg}$ and $0.90 \pm 0.61 \mathrm{~kg}$ of Cnidoscolus quercifolius leaves and fine branches (on the basis of $\mathrm{DM}$ ), respectively, that were growing in a Caatinga site that had been recovering for 3 years. If these plants resulted from the regrowth of remaining stumps, their age could be considered similar to those of the present study. Bakke (2005) observed that there was 4.1 and $1.9 \mathrm{~kg}$ of dry matter plant ${ }^{-1}$, respectively, for the first and second cutting of all the branches with $\varnothing<10 \mathrm{~mm}$ of native $M$. tenuiflora.
In contrast, Araújo et al. (2004) reported $7.3 \mathrm{~kg}$ of fresh $M$. tenuiflora leaves plant ${ }^{-1}$, when planted in a $5 \mathrm{~m} \times 5 \mathrm{~m}$ grid. This data shows the potential of forage production in Caatinga trees.

Dry matter content was not affected $(\mathrm{P}>0.05)$ by branch cutting intensity and the type of forage material collected. It averaged roughly around 30\% of the collected fresh material. Neutral detergent fiber content was affected by branch cutting intensity $(\mathrm{P}<0.05)$ and type of collected forage material $(\mathrm{P}<0.05)$; it remained in a $50.57 \%-54.80 \%$ range except in sprouts from plants subjected to $100 \%$ cutting intensity, when NDF content increased to $62.20 \%$ (Table 2). Acid detergent fiber content also increased $(\mathrm{P}<0.05)$ from an average value of $38.46 \%$ in branches to approximately $46.45 \%$ in sprouts collected from plants subjected to $50 \%$ and $100 \%$ cutting intensities. This can certainly be a physiological response of the plant to branch cutting that may ultimately prevent or diminish the consumption of their leaves and fine branches by animals in addition to high levels of cyanogenic glycosides.

Table 2. Mean neutral (NDF) and acid detergent fiber (ADF) contents in forage of native Manihot glaziovii trees subjected to $33 \%, 50 \%$, and $100 \%$ of branch $(\varnothing<10 \mathrm{~mm})$ cutting intensities and in their corresponding 1 -year-old sprouts.

\begin{tabular}{|c|c|c|c|c|c|c|c|c|}
\hline \multirow[b]{3}{*}{ Branches } & \multicolumn{4}{|c|}{ NDF $(\%$ of DM) } & \multicolumn{4}{|c|}{$\mathrm{ADF}(\%$ of $\mathrm{DM})$} \\
\hline & $33 \%$ & $50 \%$ & $100 \%$ & Mean & $33 \%$ & $50 \%$ & $100 \%$ & Mean \\
\hline & 50.57 & 53.41 & 54.41 & 52.80 & 38.30 & 37.31 & 39.79 & 38.46 \\
\hline Sprouts & 52.80 & $54.80^{*}$ & 62.20 & 56.96 & 38.27 & $46.26^{*}$ & 46.63 & 43.21 \\
\hline Mean & 51.68 & 53.87 & 58.31 & & 38.29 & 40.29 & 43.21 & \\
\hline
\end{tabular}

*one replication value.

Previously reported FDN and ADF mean values of forage collected from fine branches of native $M$. glaziovii $(43 \%<\mathrm{NDF}<48 \%$ and $31 \%<\mathrm{ADF}<34 \%)$ (FRANÇA et al., 2010; SOUZA et al., 2006) are lower than those reported in the present study and show variations in fiber content within M. glaziovii, which may be due to environmental conditions.
This environment-based hypotheses is corroborated by the low fiber contents reported by Ferreira et al. (2009) for forage collected from cultivated M. glaziovii ( $\mathrm{NDF}=35.41 \%$ and $\mathrm{ADF}=21.69 \%)$, probably due to improved growing conditions that are available to the cultivated plants.

The increase in NDF content and the decrease in 
sprout-based forage production (Figure 1) at 100\% cutting intensity suggest the inadequacy of cutting all branches and sprouts every year. It is necessary to determine which cutting intensity between $50 \%$ and $100 \%$ will optimize forage production (Figure 1) and quality (Table 2).

Ingeneral, forage fromfinebranches of treesshows high NDF and ADF contents $(53.9 \%<\mathrm{NDF}<84.1 \%$, $46.5 \%<\mathrm{ADF}<70.3 \%$ ) (CORDÃO et al., 2013; COSTA et al., 2010; FORMIGA et al., 2011; SANTOS et al., 2009). However, fine branches of the well-known, but soil and water demanding, Leucaena leucocephala (Lam) may result in forage with NDF and ADF contents of $30.8 \%$ and $14.3 \%$ (SANTOS et al., 2009), respectively, and those from the xerophilous native, Poincianella pyramidalis (Tul.) L. P. Queiroz, show NDF and ADF contents of $47.1 \%$ and $28.5 \%$ (MENDONÇA JÚNIOR et al., 2008), respectively. Reports on cultivated grasses, such as Pennisetum purpureum Schum (FERREIRA et al., 2004) and Urochloa spp. (GERON et al., 2014), that are widely used to feed animals in the Caatinga show that they are productive but demand relatively high levels of soil moisture and fertility; their forage presents high fiber contents (NDF> 74\% and $\mathrm{ADF}>45 \%$ ).

Collection of forage from some Caatinga trees, such as $P$. pyramydalis and M. glaziovii, seems to be a sound practice that can be adopted in the cattle ranching activity in the Caatinga region, considering the great number of naturally established plants in the region and the quantity and quality of the forage represented by their fine branches. Specifically, for M. glaziovii, NDF content of $33 \%$ to $50 \%$ in the forage collected as branches or sprouts means that cellular content represents $45.20 \%$ or more of the collected biomass. The cellular content is the component of biomass, which is readily digested and absorbed by animals. The fibrous fraction constitutes up to $54.80 \%$ of the collected biomass and needs the digestive action of the ruminal microbiota before partial absorption.
This fiber fraction potentially absorbed by ruminants is known as hemicellulose and is calculated by $\mathrm{HC}=\mathrm{NDF}-\mathrm{ADF}$. Cutting intensity and type of collected forage material had no effect $(\mathrm{P}<0.05)$ on HM content, which remained in the range of $8.54 \%$ to $16.10 \%$. These values were similar to those reported by França et al. (2010) (12.02\%) and Souza et al. (2006) $(12.0 \%<\mathrm{HC}<14.5 \%)$ for M. glaziovii branches, although Ferreira et al. (2009) reported lower HC content value (3.7\%) for aboveground biomass from 1-year-old M. glaziovii. Hemicellulose content in fine branches of other tree species ranged from $2.6 \%$ to $22.27 \%$ (CORDÃO, 2011; COSTA et al., 2010; FORMIGA et al., 2011; MENDONÇA JÚNIOR et al., 2008; SANTOS et al., 2009). This means that, in addition to its cellular content, $2.6 \%$ to $22.27 \%$ of the ingested forage is expected to be digested and absorbed by a ruminant. For M. glaziovii, at least $45.20 \%$ (i.e., $100 \%$ - maximum NDF content, except in sprouts from plants subjected to $100 \%$ cutting intensity) of the collected branches and sprouts represent cellular content that is readily absorbed by the animals. On the other hand, at least $8.54 \%$, is represented by the minimum $\mathrm{HC}$ content, which is potentially digested by rumen microorganisms and absorbed by the animals, and thus, adds up to be $53.74 \%$ (i.e.: $45.20 \%+8.54 \%$ ) of potentially absorbed forage. For the purpose of comparison, $57.2 \%$ and $67.7 \%$ of sunflower and corn silage, respectively, is expected to be absorbed by ruminants (POSSENTI et al., 2005).

Crude protein content was not affected by cutting intensity $(\mathrm{P}>0.05)$ and type of collected forage material $(\mathrm{P}>0.05)$; it ranged from $8.72 \%$ to $10.08 \%$. These values are lower than those reported by Ferreira et al. (2009) in the aboveground biomass of cultivated 1-year-old M. glaziovii $(\mathrm{CP}=19.14 \%)$ and by França et al. (2010) and Souza et al. (2006) $(13.66 \%<\mathrm{CP}<16.56 \%)$ in fine branches of naturally occurring M. glaziovii. Certainly, these differences in $\mathrm{CP}$ content result from improved soil conditions 
(soil plowing and fertilization) or are due to the part of the plant considered in the analysis (only leaves or branches with smaller diameter). Crude protein content of other native trees is known to range from $11.25 \%<\mathrm{CP}<14.00 \%$ (CORDÃO et al., 2013; COSTA et al., 2010; FORMIGA et al., 2011; GONZAGA NETO et al., 2004; MENDONÇA JÚNIOR et al., 2008). This data shows the potential of M. glaziovii and other tree species growing in the Caatinga to produce protein-rich forage; it also suggests that trees should be maintained in the production systems of cattle ranching practiced in the region because this can help ensure quantity and quality of forage as well as soil protection and animal comfort, resulting from the presence of trees in the rangeland.

Ether extract content was not affected $(\mathrm{P}<0.05)$ by the studied factors and ranged from $2.74 \%$ to $4.35 \%$ (Table 3 ). However, considering the low number of replications $(n=2)$, the observed trend of EE reduction in sprouts should be further investigated. If this trend is confirmed, it means that branch cutting stresses the plants and that subsequent sprout collection may result in forage with even less EE, despite the nutritive reserves stored in their roots. Values of EE content observed in the present study are within the range reported in literature for this species $(2.84 \%<\mathrm{EE}<5.23 \%)$ (FRANÇA et al., 2010; SOUZA et al., 2006) as well as for two exotic trees cultivated in the region: 4.15 and $5.55 \%$ for Leucaena leucocephala branches and Gliricidia sepium (Jacq.) Walp.) leaves (BAYÃO et al., 2016), respectively. Other Caatinga trees, such as $P$. pyramidalis (GONZAGA NETO et al., 2001) and M. tenuiflora (CORDÃO et al., 2013), may show similar or higher (up to $6.53 \%$ ) EE content in their fine branches. For each species, intraspecific variation in this and other bromatological and production parameters should be determined. This information should be used to advantage in breeding programs, so that genetically improved plants could be made available to farmers.

Table 3. Mean ether extract (EE) and mineral matter (MM) contents in forage of native Manihot glaziovii trees subjected to $33 \%, 50 \%$, and $100 \%$ of branch $(\varnothing<10 \mathrm{~mm})$ cutting intensities and in the corresponding 1-year-old sprouts.

\begin{tabular}{|c|c|c|c|c|c|c|c|c|}
\hline & \multicolumn{4}{|c|}{$\mathrm{EE}(\%$ of $\mathrm{DM})$} & \multicolumn{4}{|c|}{ MM (\% of DM) } \\
\hline & $33 \%$ & $50 \%$ & $100 \%$ & Mean & $33 \%$ & $50 \%$ & $100 \%$ & Mean \\
\hline Branches & 4.35 & 3.68 & 3.29 & 3.77 & 5.52 & 5.54 & 5.53 & 5.53 \\
\hline Sprouts & 3.80 & $3.30^{*}$ & 2.74 & 3.28 & 5.58 & $6.33 *$ & 6.01 & 5.97 \\
\hline Mean & 4.08 & 3.55 & 3.02 & & 5.55 & 5.93 & 5.77 & \\
\hline
\end{tabular}

*one replication value.

Mineral matter content was not affected $(\mathrm{P}>0.05)$ by branch cutting intensity; it increased $(\mathrm{P}<0.05)$ from $5.53 \%$ in branches to $5.90 \%$ in sprouts (Table 3). Souza et al. (2006) and França et al. (2010) reported MM content of $8.08 \%$ and $9.85 \%$, respectively, in fine branches of native M. glaziovii, while reports on MM content in branches of other trees, including fine branches of M. tenuiflora (CORDÃO et al., 2013; FORMIGA et al., 2011) and Ziziphus joazeiro (COSTA et al., 2010), reported it to range from $3.78 \%$ to $7.74 \%$, respectively. Similarly, P. pyramidalis was observed to have MM content in the range $4.58 \%$ to $6.11 \%$ (GONZAGA NETO et al., 2001; MENDONÇA JÚNIOR et al., 2008).

Total carbohydrate content was not affected by cutting intensity $(\mathrm{P}>0.05)$ and type of collected forage material $(\mathrm{P}>0.05)(80.55 \%<\mathrm{TC}<82.55 \%)$, 
while NFC decreased $(\mathrm{P}<0.05)$, especially in plants subjected to $50 \%$ and $100 \%$ cutting intensities: it ranged from $27.38 \%$ to $30.23 \%$ in branches and from $20.35 \%$ to $27.75 \%$ in sprouts (Table 4 ). Lower NFC content in sprouts was unexpected because young succulent parts of a plant, such as 1-year-old sprouts, are supposed to show higher NFC content as opposed to structural carbohydrates that tend to accumulate in the woody tissues of older parts of a plant, such as the branches that are cut from plants left to recover for six years (the period from 2004, when the plants were fully cut, to 2010, when only branches were collected to provide data for this study). França et al. (2010) reported CT and NFC contents lower than and within the range of the values observed in the present study (68.76\% and 25.94, respectively) in fine branches of native $M$ glaziovii trees, while Souza et al. (2006) observed TC and NFC contents of $79.56 \%$ and $20.34 \%$, respectively, in silage of fine branches of this species.

Table 4. Mean total (TC) and non-fibrous (NFC) carbohydrate contents in forage of native Manihot glaziovii trees subjected to $33 \%, 50 \%$, and $100 \%$ branch $(\varnothing<10 \mathrm{~mm})$ cut intensities and respective 1-year-old sprouts.

\begin{tabular}{|c|c|c|c|c|c|c|c|c|}
\hline & \multicolumn{4}{|c|}{$\mathrm{TC}(\%$ of $\mathrm{DM})$} & \multicolumn{4}{|c|}{ NFC $(\%$ of DM) } \\
\hline & $33 \%$ & $50 \%$ & $100 \%$ & Mean & $33 \%$ & $50 \%$ & $100 \%$ & Mean \\
\hline Branches & 80.79 & 80.79 & 82.16 & 81.25 & 30.23 & 27.38 & 27.75 & 28.45 \\
\hline Sprouts & 80.55 & $80.90 *$ & 82.54 & 81.33 & 27.75 & $23.85^{*}$ & 20.35 & 23.98 \\
\hline Mean & 80.67 & 80.85 & 82.35 & & 28.99 & 25.62 & 24.05 & \\
\hline
\end{tabular}

*one replication value.

Native trees in the Caatinga Biome, such as $P$. pyramidalis and $M$. tenuiflora show $\mathrm{TC}$ and NFC contents ranging from $80.00 \%<$ TC $<81.00 \%$ and $23.26 \%<\mathrm{NFC}<34.11 \%$, respectively, in their branches. Also, NFC content in fine branches of Z. joazeiro is as low as $14.36 \%$ (CORDÃO et al., 2013; COSTA et al., 2010; MENDONÇA JÚNIOR et al., 2008). This data shows that the forage of fine branches collected from M. glazioviiand and other Caatinga trees is relatively rich in NFC. More importantly, however, this data set shows clearly that the quality of forage produced by Caatinga trees varies within and between species, probably resulting from different phenophase and the nature of the part of the plant collected, soil conditions, and genetics. Specifically, for native $M$. glaziovii - a native tree representing numerous plants in the Caatinga Biome - it is possible to cut $50 \%$ of its fine branches as well as corresponding sprouts in order to collect more than $1.7 \mathrm{~kg}$ plant $^{-1}$ (on the basis of $\mathrm{DM}$ ) of forage appropriate to feed ruminants.

\section{Conclusions}

Native Manihot glaziovii trees in Itapetim-PE, Brazil may have no more than $50 \%$ of their fine $(\varnothing<10 \mathrm{~mm})$ branches and corresponding 1-yearold sprouts cut without reduction in growth and forage quantity and quality. Thus, they can produce up to $1.73 \mathrm{~kg}$ of forage per plant on the basis of their DM, especially when bromatological qualities appropriate to feed ruminants are to be maintained.

\section{References}

ARAÚJO, L. V. C.; LEITE, J. A. N.; PAES, J. B. Estimativa da produção de biomassa de um povoamento de jurema-preta (Mimosa tenuiflora (Willd.) Poiret. com cinco anos de idade. Biomassa \& Energia, Viçosa, MG, v. 1, n. 4, p. 347-352, 2004.

ARAÚJO, M. J.; MEDEIROS, A. N.; CARVALHO, F. F. R.; SILVA, D. S.; CHAGAS, E. C. O. Consumo e digestibilidade dos nutrientes em cabras Moxotó recebendo dietas com diferentes níveis de feno de maniçoba. Revista Brasileira de Zootecnia, Viçosa, MG, 
v. 38, n. 6, p. 1088-1095, 2009.

BAKKE, I. A. Potencial de acumulação de fitomassa e composição bromatológica da jurema preta (Mimosa tenuiflora (Willd.) Poiret) na região semi-árida da Paraíba. 2005. Tese (Doutorado em Agronomia) Universidade Federal da Paraíba, Areia.

BAKKE, O. A.; PEREIRA FILHO, J. M.; BAKKE, I. A.; CORDÃO, M. A. Produção e utilização da forragem de espécies lenhosas da Caatinga. In: GARIGLIO, M. A.; SAMPAIO, E. V. S. B.; CESTARO, L. A.; KAGEYAMA, P. Y. (Org.). Uso sustentável e conservação dos recursos florestais da caatinga. Brasília: Serviço Florestal Brasileiro, 2010. p. 160-173.

BAYÃO, G. F. V.; EDVAN, R. L.; CARNEIRO, M. S. S.; FREITAS, N. E.; PEREIRA, E. S.; PACHECO, W. F.; BEZERRA, L. R.; ARAÚJO, M. J. Desidratação e composição química do feno de Leucena (Leucena leucocephala) e Gliricidia (Gliricidia sepium). Revista Brasileira Saúde e Produção Animal, Salvador, v. 17, n. 3, p. 365-373, 2016.

CORDÃO, M. A. Inclusão de ramos e frutos de jurema preta (Mimosa tenuiflora (Willd.) (Poiret) e farelo de palma forrageira (Opuntia fícus-indica Mill) na dieta de cordeiros. 2011. Dissertação (Mestrado em Zootecnia) Universidade Federal de Campina Grande, Patos.

CORDÃO, M. A.; BAKKE, O. A.; PEREIRA, G. M.; SILVA, A. M. A.; NÓBREGA, G. H.; CAMPOS, E. M.; PEREIRA, H. D.; PEREIRA FILHO, J. M. Substitution of Pennisetum purpureum by Opuntia ficus-indica and Mimosa tenuiflora in the diet of lambs. Revista Brasileira de Saúde e Produção Animal, Salvador, v. 14, n. 4, p. 684-694, 2013.

COSTA, M. R. G. F.; CARNEIRO, M. S. S.; PEREIRA, E. S.; SOUTO, J. S.; MORAIS NETO, L. B.; REGADA FILHO, J. G. L.; ALENCAR, C. E. M. Comportamento ingestivo de ovinos Morada Nova recebendo dietas à base de feno de juazeiro. Revista Brasileira de Saúde e Produção Animal, Salvador, v. 11, n. 4, p. 1012-1022, 2010.

COSTA, R. G.; MESQUITA, Í. V. U.; QUEIROGA, R. C. R. E.; MEDEIROS, A. N.; CARVALHO, F. F. R.; BELTRÃO FILHO, E. M. Características químicas e sensoriais do leite de cabras Moxotó alimentadas com silagem de maniçoba. Revista Brasileira de Zootecnia, Viçosa, MG, v. 37, n. 4, p. 694-702, 2008.

DRUMOND, M. A.; SALVIANO, L. M. C.; CAVAlCANTI, N. B.; PEREIRA, L. G. R. Produção, distribuição da biomassa e composição bromatológica da parte aérea da faveleira. Revista Brasileira de Ciências Agrárias, Recife, v. 2, n. 4, p. 308-310, 2007.
FERREIRA, A. C. H.; NEIVA, J. N. M.; RODRIGUEZ, N. M.; LÔBO, R. N. B.; VASCONCELOS, V. R. Valor nutritivo das silagens de capim-elefante com diferentes níveis de subprodutos da indústria do suco de caju. Revista Brasileira de Zootecnia, Viçosa, MG, v. 33, n. 6, p. 1380-1385, 2004.

FERREIRA, A. L.; SILVA, A. F.; PEREIRA, L. G. R.; BRAGA, L. G. T.; MORAES, S. A.; ARAÚJO, G. G. L. Produção e valor nutritivo da parte aérea da mandioca, maniçoba e pornunça. Revista Brasileira de Saúde e Produção Animal, Salvador, v. 10, n. 1, p. 129-136, 2009.

FORMIGA, L. D. A. S.; PEREIRA FILHO, J. M.; NASCIMENTO JÚNIOR, N. G.; SOBRAL, F. E. S.; BRITO, I. C. A.; SANTOS, J. R. S.; SILVA, S. G. Diâmetro do caule sobre a desidratação, composição química e produção do feno de Jurema preta (Mimosa tenuiflora Willd. Poir.). Revista Brasileira de Saúde e Produção Animal, Salvador, v. 12, n. 1, p. 22-31, 2011.

FRANÇA, A. A.; GUIM, A.; BATISTA, A. M. V.; PIMENTEL, R. M. M.; FERREIRA, G. D. G.; MARTINS, I. D. S. L. Anatomia e cinética de degradação do feno de Manihot glaziovii. Acta Scientiarum Animal Sciences, Maringá, v. 32, n. 2, p. 131-138, 2010.

GERON, L. J. V.; CABRAL, L. S.; TRAUTMANNMACHADO, R. J.; ZEOULA, L. M.; OLIVEIRA, E. B.; GARCIA, J.; GONÇALVES, M. R.; AGUIAR, R. P. S. Avaliação do teor de fibra em detergente neutro e ácido por meio de diferentes procedimentos aplicados às plantas forrageiras. Semina: Ciências Agrárias, Londrina, v. 35, n. 3, p. 1533-1542, 2014.

GONZAGANETO, S.; BATISTA,A.M.V.; CARVALHO, F. F. R.; MARQUES, C. A. T.; SANTOS, G. R. A. Efeito da adição de feno de catingueira (Caesalpinea bracteosa) na ração sobre o balanço de energia e de nitrogênio em ovinos Morada Nova. Revista Brasileira de Zootecnia, Viçosa, MG, v. 33, n. 5, p. 1325-1331, 2004.

GONZAGANETO, S.; BATISTA,A.M. V.; CARVALHO, F. F. R.; MARTÍNEZ, R. L. V.; BARBOSA; J. E. A. S.; SILVA, E. O. Composição bromatológica, consumo e digestibilidade in vivo de dietas com diferentes níveis de feno de catingueira (Caesalpinea bracteosa), fornecidas para ovinos Morada nova. Revista Brasileira de Zootecnia, Viçosa, MG, v. 30, n. 2, p. 553-562, 2001.

GOUVEIA, L. N. F.; MACIEL, M. V.; SOARES, P. C.; SILVA NETO, I. F.; GONÇALVES, D. N. A.; BATISTA, A. M. V.; CARVAlHO, F. F. R. Perfil metabólico de ovinos em crescimento alimentados com dietas constituídas de feno ou silagem de maniçoba e palma forrageira. Pesquisa Veterinária Brasileira, Rio de Janeiro, v. 35, p. 5-9, 2015. Suplemento 1. 
MEDINA, F. T.; CÂNDIDO, M. J. D.; ARAÚJO, G. G. L.; BARROSO, D. D.; CRUZ, M. C. S. Silagem de maniçoba associada a fontes energéticas na alimentação de caprinos: consumo e digestibilidade. Acta Scientiarum Animal Sciences, Maringá, v. 31, n. 3, p. 265-269, 2009.

MENDONÇA JÚNIOR, A. F.; BRAGA, A. P.; GALVÃO, R. J. D. Composição bromatológica, consumo e digestibilidade in vivo de dietas com diferentes níveis de feno de catingueira (Caesalpinea pyramidalis Tul), fornecidas para ovinos SRD. Revista de Biologia e Ciências da Terra, São Cristóvão, v. 8, n. 1, p. 135-142, 2008.

MOREIRA FILHO, E. C.; SILVA, D. S.; ANDRADE, A. P.; PARENTE, H. N.; VIANA, B. L. Crescimento vegetativo da maniçoba submetida a diferentes manejos de solo, densidades de plantio e alturas de corte. Revista Caatinga, Mossoró, v. 21, n. 4, p. 147-153, 2008.

POSSENTI, R. A.; FERRARI JUNIOR, E.; BUENO, M. S.; BIANCHINI, D.; LEINZ, F. F.; RODRIGUES, C. F. Parâmetros bromatológicos e fermentativos das silagens de milho e girassol. Ciência Rural, Santa Maria, v. 35, n. 5, p. 1185-1189, 2005.

PRESTES, N. E.; AMARANTE, C. V. T.; PINTO, C. E.; PRESTES, G.; ZANINI, G. D.; MEDEIROS-NETO, C.; SBRISSIA, A. F. Forage production in a natural grassland with limestone and phosphorus dosages. Semina: Ciências Agrárias, Londrina, v. 37, n. 5, p. 3265-3276, 2016.

RAMOS, A. O.; FERREIRA, M. A.; SANTOS, D. C.; VÉRAS, A. S. C.; CONCEIÇÃO, M. G.; SILVA, E. C.; SOUZA, A. R. D. L.; SALLA, L. E. Associação de palma forrageira com feno de maniçoba ou silagem de sorgo e duas proporções de concentrado na dieta de vacas em lactação. Arquivo Brasileiro de Medicina Veterinária e Zootecnia, Belo Horizonte, v. 67, n. 1, p. 189-197, 2015.
SANTOS, E. M.; ZANINE, A. M.; FERREIRA, D. J.; OLIVEIRA, J. S.; PEREIRA, O. G.; CECON, P. R.; EDVAN, R. L.; VASCONCELOS, W. A. Composição química e degradabilidade in situ da matéria seca de leguminosas no Semi-árido baiano. Archives of Veterinary Science, Curitiba, v. 14, n. 2, p. 96-102, 2009.

SILVA, D. J.; QUEIROZ, A. C. Análises de alimentos: métodos químicos e biológicos. 3. ed. Viçosa, MG: Editora UFV, 2002. $235 \mathrm{p}$.

SILVA, T. G. P.; COSTA, C. R. L.; GUIM, A.; FERRAZ, L. V.; LIRA, J. T.; ABREU, K. S. F. Efeito dos métodos de conservação de forragem sobre a concentração de ácido cianídrico na maniçoba. Ciência Veterinária nos Trópicos, Recife, v. 18, n. 2, p. 135-138, 2015.

SOUZA, E. J. O.; GUIM, A.; BATISTA, A. M. V.; ZUMBA, E. R. F.; SANTOS, E. P.; SOUZA, K. S.; SANTOS, G. R. A.; LINS, N. B.; MATOS, D. S. Qualidade de silagens de maniçoba (Manihot epruinosa) emurchecida. Archivos de Zootecnia, Córdoba, v. 55, n. 212, p. 351-360, 2006.

VAN SOEST, P. J.; ROBERTTSON, J. B.; LEWIS, B. A. Methods for dietary fiber, neutral detergent fiber, and non starch polysaccharides in relation to animal nutrition. Journal of Dairy Science, Champaign, v. 74, n. 10, p. 3583-3597, 1991.

VIEIRA, E. L.; CARVALHO, F. F. R.; BATISTA, A. M. V.; FERREIRA, R. L. C.; SANTOS, M. V. F.; LIRA, M. A.; SILVA, M. J.; SILVA, E. M. B. Composição química de forrageiras e seletividade de bovinos em bosque de sabiá (Mimosa caesalpiniifolia Benth.) nos períodos chuvoso e seco. Revista Brasileira de Zootecnia, Viçosa, MG, v. 34, n. 5, p. 1505-1511, 2005.

VIEIRA, S.; HOFFMANN, R. Estatística experimental. Atlas: São Paulo, 1989. 179 p. 